\title{
The V109G Polymorphism of the p27 Gene CDKN1B Indicates a Worse Outcome in Node-Negative Breast Cancer Patients
}

\author{
Thomas Schöndorfa,b Lewin Eisele ${ }^{b} \quad$ Uwe-Jochen Göhring ${ }^{c}$ \\ Markus M. Valter ${ }^{b}$ Mathias Warm ${ }^{b}$ Peter Mallmann ${ }^{b}$ Martina Becker ${ }^{b}$ \\ Roland Fechteler $^{b}$ Maria-Paz Weisshaar ${ }^{a}$ Markus Hoopmann ${ }^{b}$ \\ aDepartment of Natural Sciences, University of Applied Sciences, St. Augustin; b Department of Gynecology and \\ Obstetrics, University of Cologne, Cologne, and cJohanniter Hospital, Bonn, Germany
}

\author{
Key Words \\ Breast cancer - CDKN1B · Chemotherapy · Node \\ involvement · p27 · Polymorphism · Prognosis
}

vival. In conclusion, the determination of the CDKN1B genotype might be a powerful tool for the prognosis of patients with early breast cancer.

Copyright $\odot 2004$ S. Karger AG, Basel

\begin{abstract}
Although p27 plays a central role in cell cycle regulation, its role in breast cancer prognosis is controversial. Furthermore, the p27 gene CDKN1B carries a polymorphism with unknown functional relevance. This study was designed to evaluate p27 expression and p27 genotyping with respect to early breast cancer prognosis. 279 patients with infiltrating metastasis-free breast cancer were included in this study. p27 expression was determined in tumor tissue specimens from 261 patients by immunohistochemistry. From 108 patients, the CDKN1B genotype was examined by PCR and subsequent direct sequencing. $55.2 \%$ of the tumors were considered p27 positive. p27 expression did not correlate with any of the established parameters except for nodal involvement but significantly correlated to prolonged disease-free survival. In $35 \%$ of the tumors analyzed, the CDKN1B gene showed a polymorphism at codon 109 (V109G). The V109G polymorphism correlated with greater nodal involvement. In the node-negative subgroup, V109G correlated significantly with a shortened disease-free sur-
\end{abstract}

\section{Introduction}

Aberrant cell cycle control is a hallmark of cancer [1]. The eukaryotic cell cycle is driven by cyclin-dependent kinases (CDKs) and negatively regulated by CDK inhibitors (CKIs) [2]. Abnormal function of CKIs can cause the deregulated proliferative activity frequently seen in tumor cells. The group of CKIs consists of two families, the Ink4 family (p16 $\left.{ }^{\text {Ink4a }}, \mathrm{p} 15^{\text {Ink4b }}, \mathrm{p} 18^{\text {Ink4c }}, \mathrm{p} 19^{\text {Ink4d }}\right)$ and the Cip/Kip family (p21 Cip1, p27Kip1, p57Kip2). The low-molecular-weight isoform of cyclin $\mathrm{E}$ is thought to be one of the most prominent factors overstimulating cell cycle progression in breast cancer [3]. The CKI p27Kip1 inhibits activation of cyclin E-cdk2 complexes and, therefore, plays a pivotal role in the progression from the G1 to the $S$ phase of the cell cycle [4]. The central role of p27 makes the protein attractive as a target for cancer treatment [5].

Due to the major features of p27 one would expect that altered p27 expression or p27 mutation will influence the aggressiveness of tumor cells. Accordingly, decreased p27

\begin{tabular}{ll}
\hline KARGER & @ 2004 S. Karger AG, Basel \\
1010-4283/04/0256-0306\$21.00/0 \\
$\begin{array}{l}\text { Eax+4161306 1234 } \\
\text { www.karger.com }\end{array}$ & $\begin{array}{l}\text { Accessible online at: } \\
\text { www.karger.com/tbi }\end{array}$
\end{tabular}

Thomas Schöndorf, $\mathrm{PhD}$

Department of Natural Sciences, University of Applied Sciences Bonn-Rhein-Sieg DE-53359 Rheinbach (Germany)

Tel. +492241865 585, Fax +4922418658585

E-Mail thomas.schoendorf@fh-bonn-rhein-sieg.de 
expression is implicated in human tumorigenesis and oncogenic progression $[4,6]$. Although a p27 mutation is a rare event in cancer, a well-known p27 polymorphism putatively effects p27 function. Consequently, both p27 expression and polymorphism might have an effect on tumor cell behavior. Aberrant tumor cell features, especially those increasing cell growth, proliferation rate or mobility of the tumor cells, influence the prognosis of cancer patients. For node-negative breast cancer patients in particular, there is a need for prognostic parameters that enable clinicians to estimate the risk of recurrence in individual patients as well as to establish an optimized adjuvant therapy in early-stage breast cancer. For example, there are promising results that the determination of the HER-2 protein, measurements of the members of the urokinase plasminogen activator system or low-molecularweight cyclin E may fill this gap [7, 8]. However, it is not yet sufficiently proven that these parameters are the strong prognosticators that are needed [9]. Thus, they have still not been introduced into generally accepted guidelines for early breast cancer treatment $[10,11]$.

This study investigates p27 expression concomitant with the p27 polymorphism with respect to the outcome of breast cancer patients.

\section{Materials and Methods}

\section{Patients}

The study group consisted of 279 patients with infiltrating primary breast carcinomas (T1-4, N0-1) who were treated between 1983 and 1989 at our department. Patients included in the study had to lack evidence of metastases (M0) at the time of diagnosis and underwent either modified mastectomy or tumorectomy with postoperative irradiation of the breast (linear accelerator: $50 \mathrm{~Gy}$ with 10-Gy boost to the tumor bed). 102 patients underwent axillary lymph nodectomy with removal of more than 10 nodes to rule out nodal metastatic disease. No adjuvant systemic treatment was administered to node-negative patients $(n=46)$. Pre- or postmenopausal node-positive patients with negative hormone receptor status received six cycles of a chemotherapy regimen consisting of a combination of either CMF (cyclophosphamide, methotrexate and fluorouracil, 600/ $40 / 600 \mathrm{mg} / \mathrm{m}^{2}$ ) or EC (epirubicin and cyclophosphamide, 60/ $600 \mathrm{mg} / \mathrm{m}^{2}$ ), and postmenopausal node-positive patients with positive hormone receptor status were treated with $20-30 \mathrm{mg}$ tamoxifen for up to 5 years.

Histological classification and grading were based on the WHO criteria and the suggestions by Bloom and Richardson [12] as well as Scarff and Torloni [13]. Tumor staging followed the TNM system of the International Union against Cancer. Regular patient checkups including physical examinations, laboratory tests and imaging procedures were integrated into a standardized follow-up program ranging from 1 to 129 months (median 72 months), in which data were collected from all patients.

\section{p27 Expression Analysis}

p27 expression was analyzed in routinely processed blocks of formalin-fixed and paraffin-embedded surgical specimens of the primary carcinomas from 261 patients. The 3 - to $4-\mu \mathrm{m}$ sections of carcinoma tissues were mounted on 3-aminopropyl-triethoxysilane-covered glass slides. After drying and removal of paraffin with xylene (10 $\mathrm{min}$ ), the specimens were rehydrated and digested by microwave treatment for $15 \mathrm{~min}$ in citrate buffer $(10 \mathrm{mM}, \mathrm{pH} 6.0)$. The sections were incubated with a mouse monoclonal anti-human p27 antibody (IgG1 subtype, clone 1B4, Novocastra, Newcastle upon Tyne, UK) at $4^{\circ} \mathrm{C}$ for $24 \mathrm{~h}$ in a moist chamber. Non-specific immunoglobulin serum was used as a negative control, replacing the specific primary antibody. A slightly modified three-step avidin-biotin complex was used to detect the antigen-antibody complex. Secondary and tertiary antibodies were incubated at room temperature for $30 \mathrm{~min}$. Between the different incubations, slides were washed with buffer $(10 \mathrm{mM}$ Tris- $\mathrm{HCl}, \mathrm{pH} 7.4,0.9 \% \mathrm{NaCl})$. The complexes were visualized using fast-red substrate (BioGenex, San Ramon, Calif., USA) for $10 \mathrm{~min}$. Cell nuclei were counterstained with hematoxylin $(2 \mathrm{~min})$. p27 expression was evaluated semiquantitatively, as previously described, yielding an immunoreactive score ranging from 0 to 9 [14]. Tumor samples with an immunoreactive score $\geq 2$ were considered to be positive.

\section{DNA Isolation}

Tissue specimens of 108 women were included in the DNA-based analyses, including 90 with known p27 expression status. Genomic DNA was extracted from 5- to $10-\mu \mathrm{m}$ sections of the paraffin-embedded tumor tissues. The slides were stained with hematoxylin-eosin to ensure a tumor cell content $>80 \%$ of all cells. For DNA extraction the sections were transferred into a $1.5-\mathrm{ml}$ beaker. Paraffin was removed by two incubations using $600 \mu \mathrm{l}$ xylene $\left(10 \mathrm{~min}, 56^{\circ} \mathrm{C}\right)$. After centrifugation $(60 \mathrm{~s}, 16,000 \mathrm{~g})$, xylene was removed with subsequent ethanol treatment steps $(100 \%$, then $70 \%$ ethanol). The deparaffinized tissues were dried and digested overnight with proteinase $\mathrm{K}(10 \mathrm{mg} /$ $\mathrm{ml})$ at $56^{\circ} \mathrm{C}$. After deactivation of the proteinase $\mathrm{K}$ by heating to $70^{\circ} \mathrm{C}$ for $10 \mathrm{~min}$, the proteins were precipitated with $7.5 \mathrm{M}$ ammonium acetate. After a further centrifugation step, the DNA was precipitated out of the supernatant using $3 \mathrm{M}$ sodium acetate in $70 \%$ ethanol. The DNA was then washed in $70 \%$ ethanol, dried and stored until the mutation analysis was performed.

\section{Amplification of the CDKN1B Gene}

The exons of the $C D K N 1 B$ gene were amplified in three separate polymerase chain reactions; exon 1 was amplified in two PCRs. The primers used were: exon 1a, forward: 5'-ACCCGGGAGAAAGATGTCAAACGTG-3', reverse: 5'-TAGAACTCGGGCAAGCTGCССТTCT-3'; exon 1b, forward: 5'-AGTACGAGTGGCAAGAGGTG-3', reverse: 5'-ATTCTATGGTTGGGGAAGGGT-3'; exon 2, forward: 5'-GTTTTTTCTAATAAAGATTGTGTGTTC-3', reverse: 5'-GTTTACGTTTGACGTCTTCTGAG-3'. Each 50- $\mu$ l PCR was performed with $75 \mathrm{ng}$ genomic DNA, $0.2 \mathrm{~m} M$ of each dNTP, 10 pmol of each primer and $2.5 \mathrm{U}$ TaqDNA (Roche Diagnostics, Mannheim, Germany) in PCR buffer (50 $\mathrm{m} M \mathrm{KCl}, 1.5 \mathrm{mM} \mathrm{MgCl} 2$, $10 \mathrm{~m} M$ Tris/ $\mathrm{HCl}, \mathrm{pH}$ 8.3). The PCR reaction conditions consisted of denaturation, $10 \mathrm{~min}$ at $94^{\circ} \mathrm{C}, 40$ cycles (except exon 2,34 cycles) of $30 \mathrm{~s}$ at $94^{\circ} \mathrm{C}$, annealing for $90 \mathrm{~s}$ at $58.2^{\circ} \mathrm{C}$ (exon 1a), $57.4^{\circ} \mathrm{C}$ (exon 1b) or $55.4^{\circ} \mathrm{C}$ (exon 2), elongation for $90 \mathrm{~s}$ at $72^{\circ} \mathrm{C}$ and a final extension step at $72^{\circ} \mathrm{C}$ for $10 \mathrm{~min}$. Amplification of exon 1a results in a 276-base-pair (bp) fragment, exon 1b a 291-bp fragment 
Table 1. Clinical and morphological data of the study subgroup (T1-4, N0-2, $\mathrm{M} 0, \mathrm{n}=261$ ) with respect to $\mathrm{p} 27 \mathrm{kip} 1$ expression

\begin{tabular}{|c|c|c|c|c|c|c|c|}
\hline & \multicolumn{2}{|c|}{ p2 $7^{\text {kip } 1}$ negative } & \multicolumn{2}{|c|}{ p2 $7^{\text {kip } 1}$ positive } & \multicolumn{2}{|c|}{ Total } & \multirow[t]{2}{*}{$\mathrm{p}$} \\
\hline & $\mathrm{n}$ & $\%$ & $\mathrm{n}$ & $\%$ & $\mathrm{n}$ & $\%$ & \\
\hline \multicolumn{8}{|l|}{ Age } \\
\hline$<50$ years & 37 & 14.1 & 50 & 19.2 & 87 & 33.3 & \\
\hline$>50$ years & 80 & 30.7 & 94 & 36.0 & 174 & 66.7 & NS \\
\hline \multicolumn{8}{|l|}{ Menopausal status } \\
\hline Premenopausal & 28 & 10.8 & 41 & 15.7 & 69 & 26.5 & \\
\hline Perimenopausal & 18 & 6.9 & 22 & 8.4 & 40 & 15.3 & \\
\hline Postmenopausal & 71 & 27.2 & 81 & 31.0 & 152 & 58.2 & NS \\
\hline \multicolumn{8}{|l|}{ Tumor size } \\
\hline$<2 \mathrm{~cm}$ & 46 & 17.6 & 49 & 18.8 & 95 & 36.4 & \\
\hline$>2-5 \mathrm{~cm}$ & 58 & 22.2 & 69 & 26.4 & 127 & 48.7 & \\
\hline$>5 \mathrm{~cm}$ & 13 & 5.0 & 26 & 10.0 & 39 & 14.9 & NS \\
\hline \multicolumn{8}{|l|}{ Nodal status $(\mathrm{n}=252)$} \\
\hline Negative & 60 & 23.8 & 55 & 21.8 & 115 & 45.6 & \\
\hline Positive & 54 & 21.4 & 83 & 32.9 & 137 & 54.4 & 0.029 \\
\hline \multicolumn{8}{|l|}{ Tumor grade } \\
\hline GI & 24 & 9.2 & 14 & 5.4 & 38 & 14.6 & \\
\hline GII & 63 & 24.1 & 82 & 31.4 & 145 & 55.5 & \\
\hline GIII & 30 & 11.5 & 48 & 18.4 & 78 & 29.9 & NS \\
\hline \multicolumn{8}{|l|}{ Receptor status } \\
\hline Negative & 38 & 14.6 & 45 & 17.2 & 83 & 31.8 & \\
\hline Positive & 79 & 30.3 & 99 & 37.9 & 178 & 68.2 & NS \\
\hline p27kip1 & 117 & 44.8 & 144 & 55.2 & 261 & 100.0 & \\
\hline
\end{tabular}

Receptor positive $=\mathrm{ER}+/ \mathrm{PR}-, \mathrm{ER}-/ \mathrm{PR}+, \mathrm{ER}+/ \mathrm{PR}+$. Steroid hormone receptor status was considered to be positive when estrogen receptor (ER) and/or progesterone receptor (PR) were positive, and negative when both ER and PR were negative. Lymph nodes were removed in 252 cases. and PCR of exon 2 amplifies a 170-bp amplicon. Before the sequencing procedure, each PCR product was purified using microspin $\mathrm{S}$ 300-HR columns (Amersham-Bioscience, Freiburg, Germany). The PCR product was applied to the top of the column and spun at $735 \mathrm{~g}$ for $2 \mathrm{~min}$. The purified samples were collected and used immediately for sequencing.

\section{p27 Mutation Analysis}

Both strands of each PCR fragment were sequenced directly using the BigDyeTerminator Cycle Sequencing Ready Reaction Kit (Applied Biosystems, Darmstadt, Germany) as indicated by the manufacturer. In brief, $4 \mu \mathrm{l}$ of PCR product were mixed with $4 \mu \mathrm{l}$ Terminator Ready Reaction Mix and 5 pmol of the corresponding single PCR primer in a final volume of $20 \mu \mathrm{l}$. Cycle sequencing was performed by denaturation at $96^{\circ} \mathrm{C}$ for $3 \mathrm{~min}$ and 24 cycles of $96^{\circ} \mathrm{C}$ for $10 \mathrm{~s}$, annealing at the corresponding temperature (see PCR conditions) for $10 \mathrm{~s}$ and polymerization at $60^{\circ} \mathrm{C}$ for $4 \mathrm{~min}$. The sequencing products were precipitated with $2 \mu \mathrm{l} 3 \mathrm{M}$ sodium acetate, $\mathrm{pH} 4.6$, and $50 \mu \mathrm{l}$ $95 \%$ ethanol. Samples were pelleted $(16,000 \mathrm{~g}, 15 \mathrm{~min})$, washed in $70 \%$ ethanol and pelleted again. Dried samples were resuspended in $25 \mu \mathrm{l}$ template suppression reagent, denatured at $95^{\circ} \mathrm{C}$ for $1 \mathrm{~min}$ and placed on ice until sequence analysis. The sequence was detected on an automated Genetic Analyzer ABI 310 (Applied Biosystems). The sample was applied to a $47-\mathrm{cm}$ capillary, $50 \mu \mathrm{m}$ in diameter, filled with POP-6 polymer. The capillary was loaded with the sample for $30 \mathrm{~s}$ at $2.0 \mathrm{kV}$ and each analysis run for $28 \mathrm{~min}$ at $13.8 \mathrm{kV}$ (exon $1 \mathrm{a}$, $1 \mathrm{~b}$ ) or for $24 \mathrm{~min}$ at $13.6 \mathrm{kV}$ (exon 2). All sequencing data were analyzed by comparative alignments using the Sequence Navigator software (Applied Biosystems).

\section{Statistics}

Statistical analyses were performed using SPSS 10.0 (Statistical Package for the Social Sciences, Munich, Germany). The $\chi^{2}$ test was used for univariate comparison of the data. Follow-up data were analyzed using the log-rank test (Kaplan-Meier survival analysis). Multivariate analyses were based on the Cox proportional hazards model and calculated relative risks. An association between features was classified as statistically significant when the $\mathrm{p}$ value was $\leq 0.05$.

\section{Results}

\section{Expression Analysis}

The p27 protein was detected in the nuclei of tumor cells. The staining pattern in tumors was heterogeneous, revealing a mixture of positive and negative cells. Non- 
Fig. 1. Kaplan-Meier curves for disease-free survival (event $=$ relapse) with respect to p2 $7^{\text {kip1 }}$ expression.

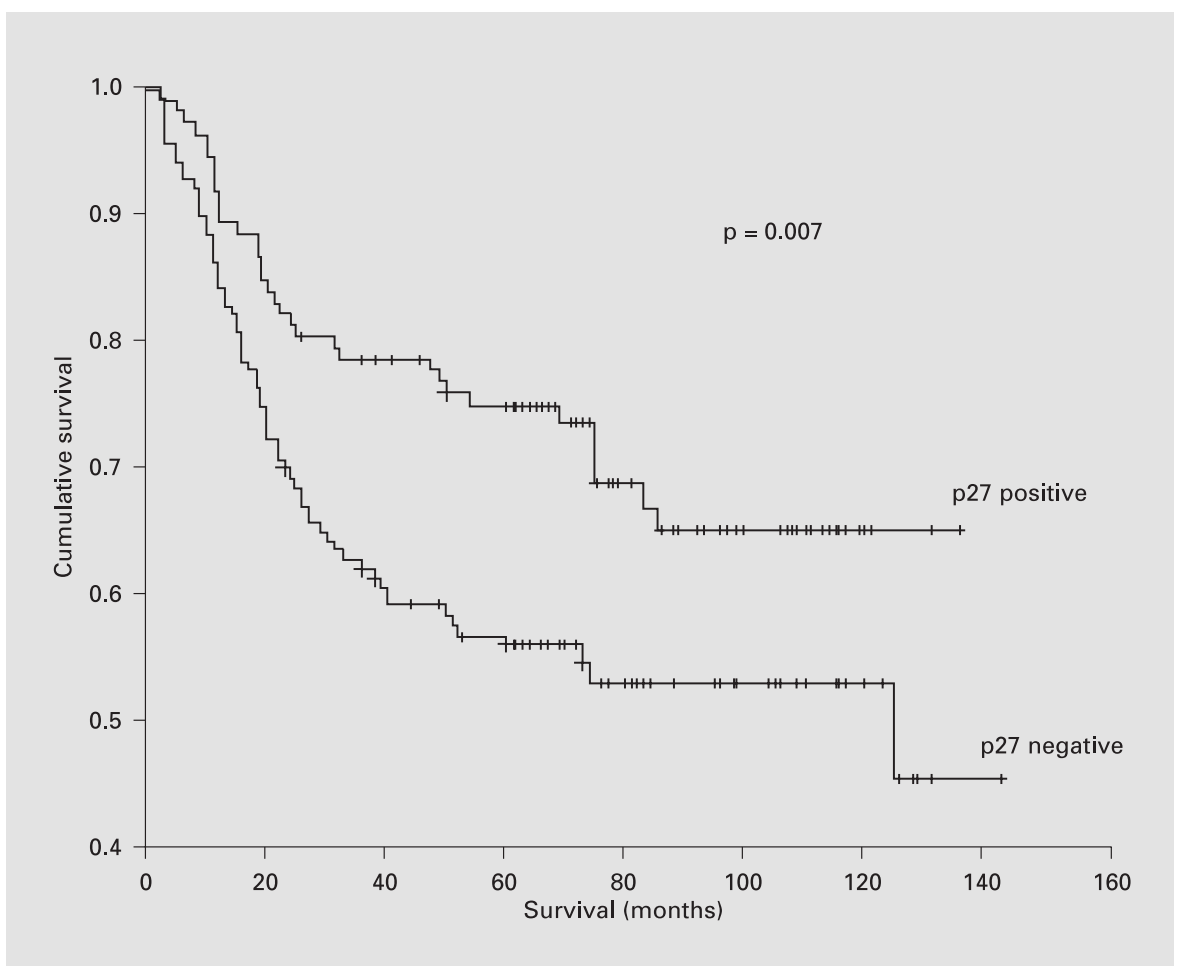

diseased lobular or ductal epithelia found in the periphery did not express detectable amounts. 144 out of the 261 specimens investigated (55.2\%) were considered p27Kip1 positive. Intracytoplasmic reactions were very rare $(7$ cases, $2.7 \%$ ). They were seen in the p27-positive subgroup (3 specimens) and very slightly in the subgroup without nuclear p27 staining (4 specimens). Table 1 summarizes the clinical and morphological data of the study group. The study group showed the expected distribution of the measured parameters. Between $\mathrm{p} 27^{\mathrm{Kip} 1}$ and the parameters studied, only for nodal involvement a significant correlation was found $(\mathrm{p}<0.05)$. In univariate analysis, a correlation between $\mathrm{p} 27^{\mathrm{Kip} 1}$ expression and patients with a positive nodal status was observed. Figure 1 displays the relation of $\mathrm{p} 27^{\mathrm{Kip} 1}$ expression with the disease-free survival of the patients. A better clinical outcome correlates significantly with $\mathrm{p} 27^{\mathrm{Kip} 1}$-positive tumors.

\section{Mutation}

The coding sequence of the $C D K N 1 B$ gene was successfully analyzed in all 108 specimens investigated. In 70 tissue specimens (65\%), DNA analysis revealed the wildtype sequence according to GenBank Accession No. NM004064. In 38 cases (35\%), a point mutation at codon 109 (GTC $\rightarrow$ GGC) was detected. The mutation results in a substitution of valine to glycine of the deduced amino acid sequence (V109G). In 9 of the 38 specimens (24\%), the base pair substitution was homozygous. In 1 case, an additional base pair substitution occurred in codon 142, ACG $\rightarrow$ ACA. This mutation does not change the amino acid coded and was therefore not further analyzed.

Table 2 summarizes the distribution of the $C D K N 1 B$ mutation with respect to standard clinical parameters and p27 expression. In patients carrying the V109G genotype, the number of lymph nodes involved was increased. There was no statistically significant correlation between the V109G genotype and disease-free survival (not shown). A further subdivision into heterozygous and homozygous mutations does not provide additional information (data not shown). The wild-type genotype showed a significantly favorable outcome for disease-free survival in the node-negative subgroup (fig. 2). There were no further statistically significant correlations in the node-positive subgroup or the entire study group (data not shown). In multivariate analysis, neither $\mathrm{p} 27$ expression nor the $C D K N 1 B$ genotype was a statistically independent parameter. 
Table 2. Clinical and morphological data of a study subgroup (T1-4, N0-2, M0, $\mathrm{n}=108$ ) with respect to $\mathrm{p} 27^{\mathrm{kip} 1}$-mutation

\begin{tabular}{|c|c|c|c|c|c|c|c|}
\hline & \multicolumn{2}{|c|}{$\begin{array}{l}C D K N 1 B \\
\text { wild type }\end{array}$} & \multicolumn{2}{|c|}{$\begin{array}{l}C D K N 1 B \\
\mathrm{~V} 109 \mathrm{G}\end{array}$} & \multicolumn{2}{|c|}{ Total } & \multirow[t]{2}{*}{$\mathrm{p}$} \\
\hline & $\mathrm{n}$ & $\%$ & $\mathrm{n}$ & $\%$ & $\mathrm{n}$ & $\%$ & \\
\hline \multicolumn{8}{|l|}{ Age } \\
\hline$<50$ years & 21 & 19.4 & 16 & 14.8 & 37 & 34.3 & \\
\hline$>50$ years & 49 & 45.4 & 22 & 20.4 & 71 & 65.7 & NS \\
\hline \multicolumn{8}{|l|}{ Menopausal status } \\
\hline Premenopausal & 18 & 16.7 & 11 & 10.2 & 29 & 26.9 & \\
\hline Perimenopausal & 8 & 7.4 & 4 & 3.7 & 12 & 11.1 & \\
\hline Postmenopausal & 44 & 40.7 & 23 & 21.3 & 67 & 62.0 & NS \\
\hline \multicolumn{8}{|l|}{ Tumor size } \\
\hline$<2 \mathrm{~cm}$ & 31 & 28.7 & 13 & 12.0 & 44 & 40.7 & \\
\hline$>2-5 \mathrm{~cm}$ & 33 & 30.6 & 17 & 15.7 & 50 & 46.3 & \\
\hline$>5 \mathrm{~cm}$ & 6 & 5.6 & 8 & 7.4 & 14 & 13.0 & NS \\
\hline \multicolumn{8}{|l|}{ Nodal status $(\mathrm{n}=102)$} \\
\hline Negative & 35 & 34.3 & 11 & 10.8 & 46 & 45.1 & \\
\hline $1-3$ nodes & 24 & 23.5 & 12 & 11.8 & 36 & 35.3 & \\
\hline$>4$ nodes & 7 & 6.8 & 13 & 12.8 & 20 & 19.6 & 0.006 \\
\hline \multicolumn{8}{|l|}{ Tumor grade } \\
\hline GI & 10 & 9.3 & 6 & 5.6 & 16 & 14.8 & \\
\hline GII & 39 & 36.1 & 21 & 19.4 & 60 & 55.6 & \\
\hline GIII & 21 & 19.4 & 11 & 10.2 & 32 & 29.6 & NS \\
\hline \multicolumn{8}{|l|}{ Receptor status } \\
\hline Negative & 17 & 16.0 & 10 & 9.4 & 27 & 25.5 & \\
\hline Positive & 52 & 49.1 & 27 & 25.5 & 79 & 74.5 & NS \\
\hline \multicolumn{8}{|l|}{$\mathrm{p} 27^{\mathrm{kip} 1}(\mathrm{n}=90)$} \\
\hline Negative & 22 & 24.4 & 19 & 21.1 & 41 & 45.6 & \\
\hline Positive & 34 & 37.8 & 15 & 16.7 & 49 & 54.4 & NS \\
\hline$C D K N 1 B$ & 70 & 64.8 & 38 & 35.2 & 108 & 100.0 & \\
\hline
\end{tabular}

Receptor positive $=\mathrm{ER}+/ \mathrm{PR}-, \mathrm{ER}-/ \mathrm{PR}+, \mathrm{ER}+/ \mathrm{PR}+, \mathrm{n}=106$. Steroid hormone receptor status was considered to be positive when estrogen receptor (ER) and/or progesterone receptor (PR) were positive, and negative when both ER and PR were negative. Steroid hormone receptor status was known from 106 specimens, p2 $7^{\text {kip } 1}$ expression in 90 cases. Lymph nodes were removed in 102 cases.

\section{Discussion}

It is well established that decreased $\mathrm{p} 27$ expression is a significant predictor of a poor outcome [15-18]. Accordingly, p27 positivity correlates to a better outcome [19]. However, in more recent investigations, p27 expression was not a significant prognosticator in multivariate analysis [14, 20-22]. In our study, p27 expression is significantly correlated to a favorable outcome, but lacks statistical significance in multivariate analysis. These data are in line with earlier reports showing that $\mathrm{p} 27$ plays a crucial role in the biology of tumors. However, p27 determination is not routinely used in the clinical setting [8, 23, 24]. In our study p27 expression correlates with lymph node metastases, intrinsically indicating a worse outcome. The phenomenon we observed remains to be elucidated. Per- haps tumor cells beginning to spread from their regular environment respond with an increase in p27 expression and consequent reduction in their proliferation rate.

The V109G polymorphism of the CDKN1B gene was first described in 1995 [25]. The polymorphism was found in 11-26\% of cancer patients, but also in approximately $39 \%$ of healthy individuals [26] and in non-malignant cells of cancer tissue specimens [27]. Unlike in advanced prostate carcinoma where it is associated with an increased risk [28], the p27/V109G phenotype was considered to be unrelated to breast cancer development $[25,26]$. To our knowledge, we present here the first report studying p27 expression concomitant with $C D K N 1 B$ polymorphism with respect to outcome in breast cancer patients. The p27 genotype is not related to p27 expression, i.e. p27 expression is independent of the 
Fig. 2. Kaplan-Meier curves for disease-free survival (event $=$ relapse) with respect to p27kip1 mutation in the node-negative subgroup $(n=46)$.

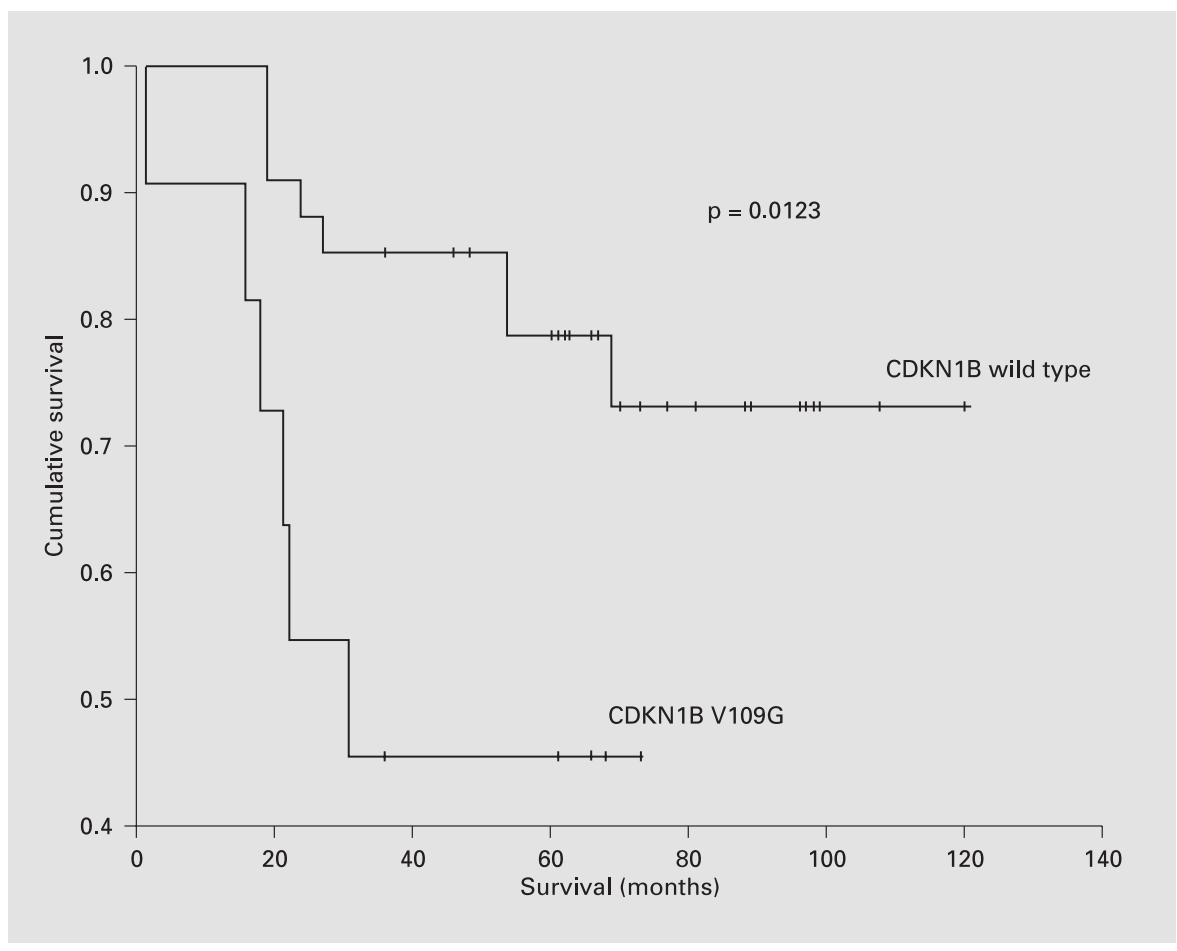

V109G polymorphism. In the node-negative subgroup, the V109G polymorphism indicates a significantly shortened disease-free survival of the patients. Due to its occurrence in non-malignant tissues, it is generally accepted that the polymorphism does not functionally impair p27 [26]. However, it is tempting to speculate the existence of a cofactor that distinguishes between wildtype p27 and p27 with the V109G mutation (p27/V109G) in breast cancer cells. This cofactor might be involved in nuclear export - or degradation - mechanisms and, as a consequence, affects the regulation of $\mathrm{p} 27 / \mathrm{V} 109 \mathrm{G}$. It is well known that increased degradation of p27 leads to a deregulated cell cycle [29, 30]. Cellular degradation systems might favor degradation of p27/V109G over wildtype $\mathrm{p} 27$. The physical connection of $\mathrm{p} 27$ to the Jun activation domain binding protein 1 (JAB1) triggers the proteolytic p27 degradation [29, 31]. The Jun-binding site is located between amino acids 97 and 151 of the p27 protein, thus including the polymorphic site. Moreover, p27/ V109G might be the favored target for protein-kinase-Bmediated phosphorylation. p27 phosphorylation attenuates or prevents p27-mediated growth arrest [32-34].

Our data indicate that $\mathrm{p} 27 / \mathrm{V} 109 \mathrm{G}$ might be a prognostic indicator for disease-free survival in node-negative breast cancer patients. The data are in line with the observation that in the entire study group the polymorphism correlates with nodal spreading of the tumor cells. The node-negative patients in our study did not receive any adjuvant therapy, thus excluding chemotherapy as the cause of the effect observed. In clinical practice, further studies are underway to determine factors that might help to distinguish between patients with an unfavorable prognosis, hereupon needing more intensified systemic treatment, and patients with a more favorable prognosis, for whom chemo- or hormonal therapy could be applied at a lower dosage or even avoided. At present, a large number of patients with node-negative breast tumors are treated improperly, while patients who need more aggressive treatment cannot be precisely identified.

In conclusion, although our results need to be verified in a larger patient cohorts, V109G determination might be a powerful tool to assist in the decision of an appropriate regimen applicable in the treatment of node-negative breast cancer patients.

\section{Acknowledgments}

This work was supported by the 'Köln Fortune' Program, University of Cologne, Medical Center, Germany. The Genetic Analyzer was financially supported by a grant from the 'Rudolf-Bartling-Stiftung', Hannover, Germany, to U.J.G. We are obliged to Ivor Smith for his linguistic assistance. 


\section{References}

1 Sherr CJ: Cancer cell cycles. Science 1996;274: 1672-1677.

12 Jacks T, Weinberg RA: The expanding role of cell cycle regulators. Science 1998;280:10351036.

$\checkmark 3$ Wingate H, Bedrosian I, Akli S, Keyomarsi K: The low molecular weight (LMW) isoforms of cyclin E deregulate the cell cycle of mammary epithelial cells. Cell Cycle 2003;2:461-466.

4 Alkarain A, Slingerland J: Deregulation of p27 by oncogenic signalling and its prognostic significance in breast cancer. Breast Cancer Res 2004;6:13-21.

$\checkmark 5$ Blain SW, Scher HI, Cordon-Cardo C, Koff A p27 as a target for cancer therapeutics. Cancer Cell 2003;3:111-115.

6 Alkarain A, Jordan R, Slingerland J: p27 deregulation in breast cancer: Prognostic significance and implications for therapy. J Mammary Gland Biol Neoplasia 2004;9:67-80.

7 Esteva FJ, Hortobagyi GN: Prognostic markers in early breast cancer. Breast Cancer Res 2004; 6:109-118.

8 Hayes DF: Markers of increased risk for failure of adjuvant therapies. Breast 2003;12:543549.

-9 Isaacs C, Stearns V, Hayes DF: New prognostic factors for breast cancer recurrence. Semin Oncol 2001;28:53-67.

10 Glen H, Jones RJ: 8th international conference: Primary therapy of early breast cancer, St. Gallen, Switzerland, March 12-15 2003. Breast Cancer Res 2003;5:198-201.

11 Kramer R: 26th Annual San Antonio Breast Cancer Symposium, San Antonio, Texas, USA, 3-6 December 2003: Update on clinical research. Breast Cancer Res 2004;6:84-87.

12 Bloom HJ, Richardson WW: Histological grading and prognosis in breast cancer. Br J Cancer 1957;11:359-377.

13 Scarff RW, Torloni H: Histological typing of breast tumors. International Histological Classification of Tumors. Geneva, World Health Organization 1968, vol 2, pp 13-20.

14 Schöndorf T, Göhring UJ, Becker M, Hoopmann M, Schmidt T, Rützel S, Rein DT, Ulrich U, Fechteler R, Bersch A, Mallmann P, Valter MM: High apoptotic index correlates to p21 and p27 expression indicating a favorable outcome of primary breast cancer patients, but lacking prognostic significance in multivariate analysis. Pathobiology 2004;71:217-222.

- 15 Tan P, Cady B, Wanner M, Worland P, Cukor B, Magi-Galluzzi C, Lavin P, Draetta G, Pagano M, Loda M: The cell cycle inhibitor p27 is an independent prognostic marker in small $\left(\mathrm{T}_{\mathrm{Ia}, \mathrm{b}}\right)$ invasive breast carcinomas. Cancer Res 1997;57:1259-1263.
16 Catzavelos C, Bhattacharya N, Ung YC, Wilson JA, Roncari L, Sandhu C, Shaw P, Yeger H, Morava-Protzner I, Kapusta L, Franssen E, Pritchard KI, Slingerland JM: Decreased levels of the cell-cycle inhibitor p27Kip1 protein: Prognostic implications in primary breast cancer. Nat Med 1997;3:227-230.

17 Tsuchiya A, Zhanf GJ, Kanno M: Prognostic impact of cyclin-dependent kinase inhibitor p2 $7^{\text {Kip1 }}$ in node-positive breast cancer. J Surg Oncol 1999;70:230-234.

18 Han S, Park K, Bae BN, Kim KH, Kim HJ, Kim YD, Kim HY: Prognostic implication of cyclin E expression and its relationship with cyclin D1 and p27Kip1 expression on tissue microarrays of node negative breast cancer. J Surg Oncol 2003;83:241-247.

19 Leivonen M, Nordling S, Lundin J, von Boguslawski K, Haglund C: p27 expression correlates with short-term, but not with long-term prognosis in breast cancer. Breast Cancer Res Treat 2001;67:15-22.

20 Porter PL, Malone KE, Heagerty PJ, Alexander GM, Gatti LA, Firpo E, Daling JR, Roberts $\mathrm{JM}$ : Expression of cell-cycle regulators p27 Kip1 and cyclin $\mathrm{E}$, alone and in combination, correlate with survival in young breast cancer patients. Nat Med 1997;3:222-225.

21 Gillet CE, Smith P, Peters G, Lu X, Barnes DM: Cyclin-dependent kinase inhibitor $\mathrm{p} 27^{\mathrm{Kip} 1}$ expression and interaction with other cell cycle-associated proteins in mammary carcinoma. J Pathol 1999;187:200-206.

22 Barbareschi M, van Tinteren H, Mauri FA, Veronese S, Peterse H, Maisonneuve P, Caffo O, Sciaoli M, Doglioni C, Galligioni E, Dalla PP, Michaelides R: p27Kip1 expression in breast carcinomas: An immunohistochemical study on 512 patients with long-term follow-up. Int J Cancer 2000;89:236-241.

23 Cariou S, Catzavelos C, Slingerland JM: Prognostic implications of expression of the cell cycle inhibitor protein p27 Kip1. Breast Cancer Res Treat 1998;52:29-41.

24 Barnes A, Pinder SE, Bell JA, Paish EC, Wencyk PM, Robertson JF, Elston CW, Ellis IO: Expression of $\mathrm{p} 27^{\mathrm{Kip} 1}$ in breast cancer and its prognostic significance. J Pathol 2003;201: 451-459.

25 Kawamata N, Morosetti R, Miller CW, Park D, Spirin KS, Nakamaki T, Takeushi S, Hatta Y, Simpson J, Wilczynski S, Lee YY, Bartram CR, Koeffler HP: Molecular analysis of the cyclindependent Kinase Inhibitor Gene p27/Kip1 in human malignancies. Cancer Res 1995;55: 2266-2269.
26 Ferrando AA, Balbin M, Pendás AM, Vizosos F, Velasco G, López-Otín C: Mutational analysis of the human cyclin-dependent kinase inhibitor p27kip1 in primary breast carcinomas. Hum Genet 1996;97:91-94.

27 Ponce-Castañeda V, Lee MH, Latres E, Polyak $\mathrm{K}$, Lacombe L, Montgomery K, Methew S, Krauter K, Sheinfeld J, Massague J, CordonCardo C: p27: Chromosomal mapping to 12 p12-12p13.1 and absence of mutations in human tumors. Cancer Res 1995;55:12111214

28 Kibel AS, Suarez BK, Belani J, Oh J, Webster R, Brophy-Ebbers M, Guo C, Catalona WJ, Picus J, Goodfellow PJ: CDKN1A and CDKN1B polymorphisms and risk of advanced prostate carcinoma. Cancer Res 2003; 63:2033-2036.

29 Tomoda K, Kubota Y, Kato J: Degradation of the cyclin-dependent kinase inhibitor p27 Kip1 is instigated by Jab1. Nature 1999;398:160165.

30 Slingerland J, Pagano M: Regulation of the cdk inhibitor p27 and its deregulation in cancer. J Cell Physiol 2000;183:10-17.

31 Esteva FJ, Sahin AA, Rassidakis GZ, Yuan LX, Smith TL, Yang Y, Gilcrease MZ, Cristofanilli M, Nahta R, Pusztai L, Claret FX: Jun activation domain binding protein 1 expression is associated with low p27 $7^{\mathrm{Kip} 1}$ levels in node negative breast cancer. Clin Cancer Res 2003;9:5652-5659.

32 Viglietto G, Motti ML, Bruni P, Melillo RM, D'Alessio A, Califano D, Vinci F, Chiappetta G, Tsichlis P, Bellacosa A, Fusco A, Santoro M: Cytoplasmic relocalization and inhibition of the cyclin-dependent kinase inhibitor p27(Kip1) by PKB/Akt-mediated phosphorylation in breast cancer. Nat Med 2002;8:11361144.

33 Shin I, Yakes FM, Rojo F, Shin NY, Bakin AV, Baselga J, Arteaga CL: PKB/Akt mediates cellcycle progression by phosphorylation of p27(Kip1) at threonine 157 and modulation of its cellular localization. Nat Med 2002;8:11451152.

34 Liang J, Zubovitz J, Petrocelli T, Kotchetkov R, Connor MK, Han K, Lee JH, Ciarallo S, Catzavelos C, Beniston R, Franssen E, Slingerland JM: PKB/Akt phosphorylates p27, impairs nuclear import of p27 and opposes p27mediated G1 arrest. Nat Med 2002;8:11531160 . 